\title{
Ontology-Based Semantic Retrieval for Durian Pests and Diseases Control System
}

\author{
Porawat Visutsak
}

\begin{abstract}
In Southeast Asia, durian is affectionately called the king of fruit. Durian is the most popular crop planted in eastern and southern of Thailand. The total crop is around 600,000 tons per year; among this, 500,000 tons of the total production were exported worldwide. In Thailand, the knowledge of durian production is based on experience from generation to generation, especially the knowledge of durian pests and diseases control. This paper presents the ontology knowledge based for durian pests and diseases retrieval system. The major contributions of the system consist of 1) the stored knowledge of durian pests and diseases and 2) the diagnosis of durian diseases and the suggestions for the treatments. The ontology knowledge consists of 8 main classes: 1) diseases, 2) pests, 3) cultivars, 4) symptoms of bunch, 5) leaf area symptoms, 6) symptoms of the branches and trunk, 7) symptoms of fruit, and 8) symptoms of root and growth. The experimental results yielded $100 \%$ of precision, $88.33 \%$ of recall, and $93.8 \%$ of overall performance.
\end{abstract}

Index Terms-Ontology, semantic web, durian cultivars, durian pests, durian diseases, information retrieval.

\section{INTRODUCTION}

Thailand has a favorable weather condition and productive land for the cultivation of tropical fruits. The fruits productions of Thailand have been considered as the premium fruits and there are high demands in the international markets. It can generate high export incomes which accounts for US\$360.89 million in 2016 [1]. In Southeast Asia, Thailand is the main supplier and exporter of tropical fruits such as durian, guavas, mangoes, mangosteens, bananas, oranges, rambutans, coconuts, and lychee. In 2017, durian production accounted for 600,000 tons and the export values accounted for over US\$ 301.75 million [1]. In Thailand, there are 234 varieties registered with the government of which about 60-80 varieties are commercially cultivated [2]. Generally, Thai durian cultivars can be divided into 3 groups according to maturity indices:

1) Early maturity (103-105 days); there are 3 cultivars in this group: Chanee, Gradum-tong and Lueng.

2) Medium maturity (127-130 days); there are 3 cultivars in this group: Monthong, Gob, and Kan Yau.

3) Late maturity (140-150 days); there are 3 cultivars in this group: Gumpan, Enak, and Tong-yoi-chat.

Manuscript received February 15, 2020; revised July 3, 2020.

Porawat Visutsak is with the Department of Computer and Information Science, Faculty of Applied Science, KMUTNB, Bangkok, Thailand (email: porawatv@kmutnb.ac.th).
According to the 3 groups of maturity indices, the 3 most popular cultivars are Monthong, Chanee and Kanyao (see Fig. 1). Durian is the most popular crop planted in eastern and southern of Thailand, of all the cultivated durian areas in Thailand; Monthong comprises $41 \%$, Chanee 33\%, Kan Yau 5\%, Gradum-tong 2\%, and the rest are minor varieties [2].

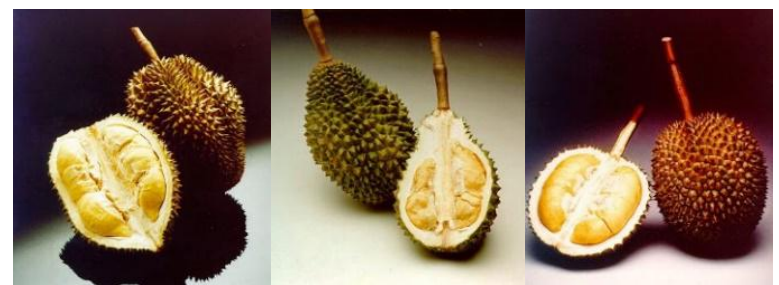

Fig. 1. Three most popular Thai durian varieties: Monthong, Chanee and Kanyao (from left to right, respectively). (www.ditp.go.th).

Although the increasing popularity of durian in world market that caused the price had risen up to 20 times over in four years [3], there is no repository to keep the technical aspects of durian production in the right place. The knowledge of durian production is still based on experience from generation to generation, especially the knowledge of durian pests and diseases control [4], [5]. This paper presents the ontology knowledge based for durian pests and diseases retrieval system. The ontology knowledge consists of 8 main classes: 1) diseases, 2) pests, 3) cultivars, 4) symptoms of bunch, 5) leaf area symptoms, 6) symptoms of branches and trunk, 7) symptoms of fruit, and 8) symptoms of root and growth. This paper is organized as follows. Section II describes the experimental framework used in this paper (the knowledge acquisition, the ontology base development, and the sematic search system). Section III describes the results. Finally, Section IV presents the conclusions and future works.

\section{SYSTEM FRAMEWORK}

The major contributions of the system consist of 1) the stored knowledge of durian pests and diseases and 2) the diagnosis of durian diseases and the suggestions for the treatments. Fig. 2 shows the system framework.

The system framework consists of 3 main parts:

\section{A. The Knowledge Acquisition}

In this step, we collected the knowledge of durian production, durian pests and diseases control from the experienced farmers in eastern and southern of Thailand by using the in-depth interview [6]. We also collected the research reports, books, and articles from the Agricultural Research Development Agency in Thailand [7]. We provide the major diseases and pests of durian in the appendix. 


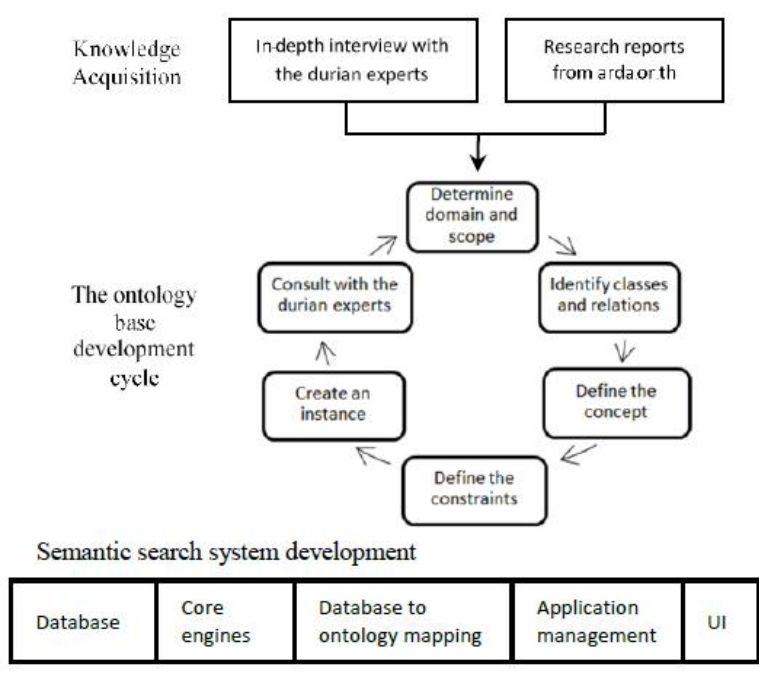

Fig. 2. The system framework.
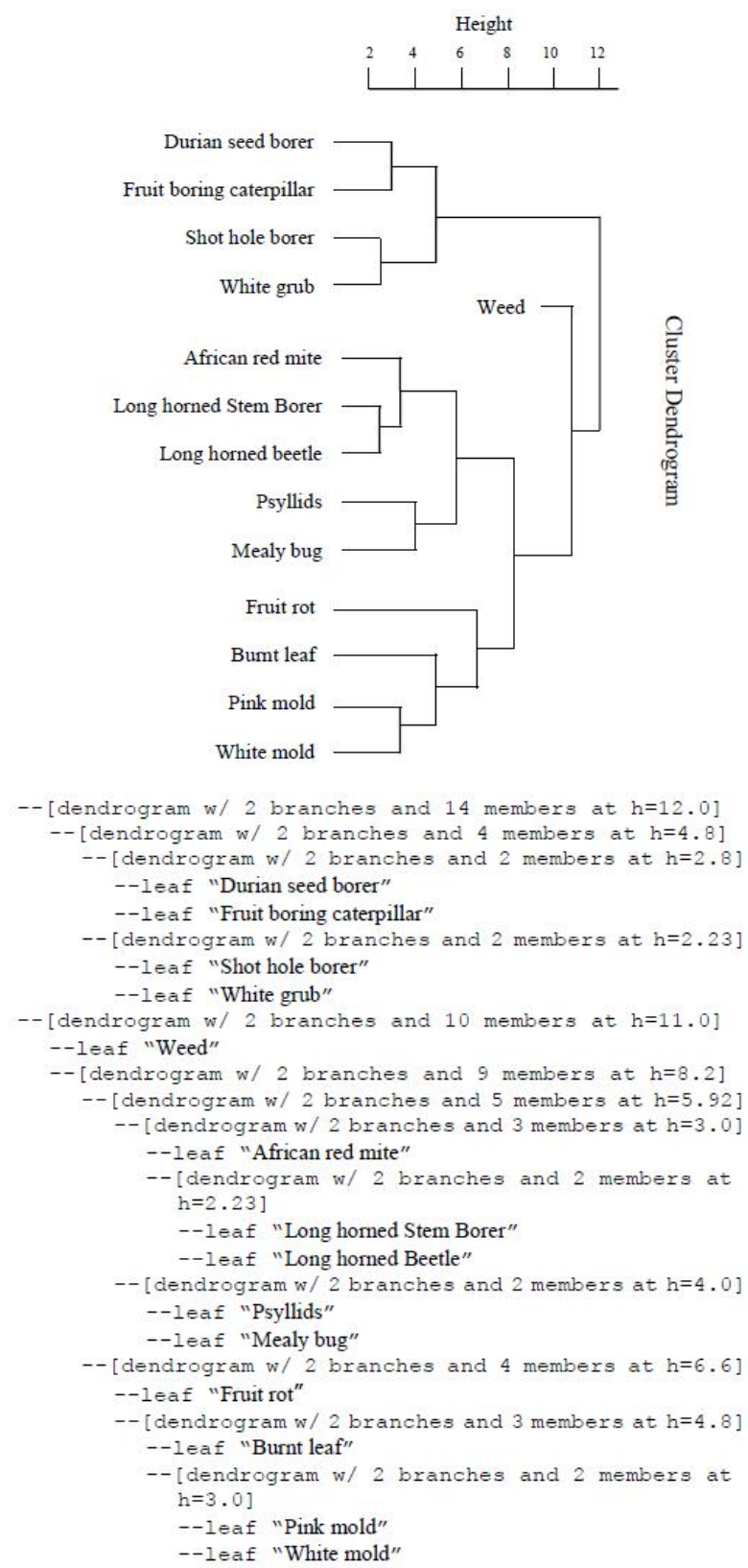

Fig. 3. The dendrogram of durian pests and diseases.

\section{B. The Ontology Base Development Cycle}

After gathering the knowledge and checking the correctness in the first step, we developed the knowledge ontology by adopting from the two frameworks presented in [8] and [9] (we surveyed many literatures about creating and processing knowledge ontology, and we found that these 2 frameworks were appropriated for the ontology in the agricultural knowledge. The ontology base development consists of 6 consecutive steps:

1) Define Determining the domain and scope of the ontology-based system; as we mentioned earlier; the system has been designed and developed for the diagnosis of durian diseases and pests, therefore the system can give the suggestions for the treatments. By the collecting the tacit knowledge of the durian farmers from generation to generation, and the best practices of durian production from the Agricultural Research Development Agency in Thailand, the system also gives the suggestions of durian production plan based on the soil conditions, weathers, and rainfall in each year.

2) Identifying classes and relations; the ontology knowledge consists of 8 main classes: 1) diseases, 2) pests, 3) cultivars, 4) symptoms of bunch, 5) leaf area symptoms, 6) symptoms of branches and trunk, 7) symptoms of fruit, and 8) symptoms of root and growth.

3) Defining the concept; we defined the properties into 3 types (IS-A, p/o, and a/o; we demonstrated the hierarchy clustering using the Dendrogram as shown in Fig. 3):

a) "IS-A" e.g., Powdery mildew is-a durian disease.

b) "part-of" e.g., Anthracnose symptoms on the durian bunch part-of ( $\mathrm{p} / \mathrm{o})$ durian disease.

c) "attribute-of" e.g., Disease_cause attribute-of (a/o) durian disease.

4) Defining the constraints, e.g., classes Growth has 2 constraints: grow slowly and die.

5) Creating an instance, e.g., the spots on the leaf is the instance of the Leaf spot disease.

6) Rechecking the concept by consulting the experts.

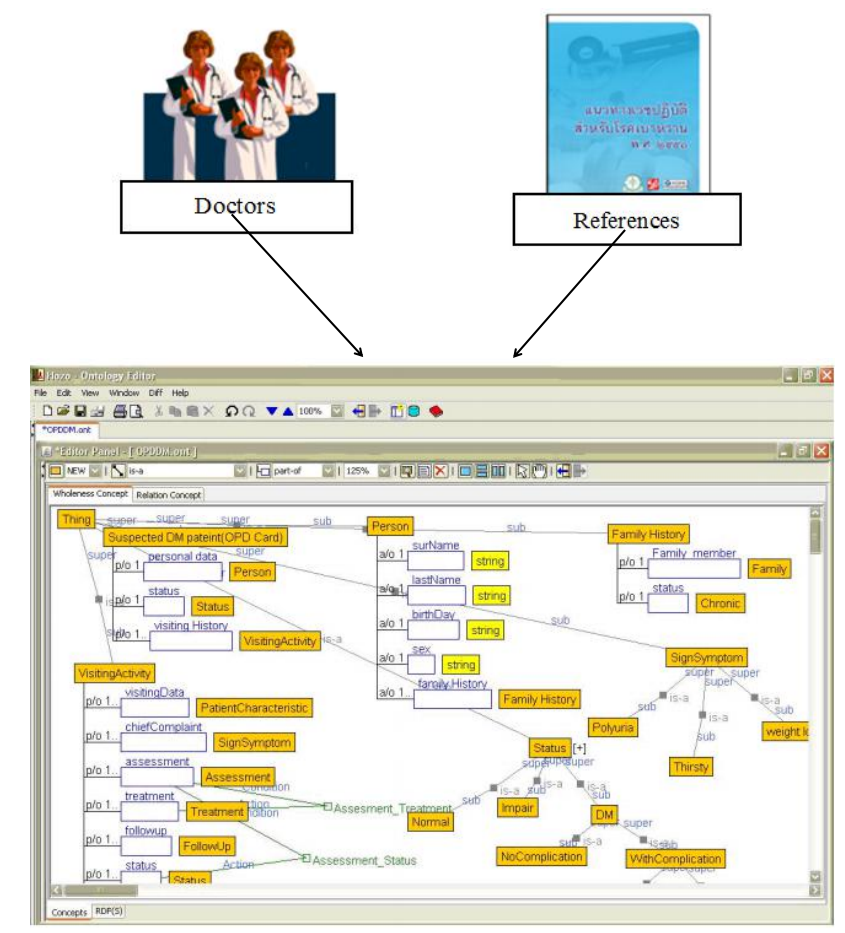

Fig. 4. The ontology editor.

As mentioned earlier, to construct the knowledge, the knowledge acquisition and modeling based on knowledge 
engineering approach required an effective tools for capturing expert opinion in form of durian pests and diseases control practice guidelines. We investigated many tools to use as the ontology editor, and we found that Protégé [10] and Hozo [11] are now the well-known ontology editors. Fig. 4 shows the example of the Hozo ontology editor used in the ontology-based clinical reminder system for diabetes patient registry [12]. Based on the Hozo ontology editor, we built the model of structural knowledge from the durian farmers and the white papers or the best practices from the Agricultural Research Development Agency in Thailand.

The Ontology-based Semantic Retrieval for Durian Pests and Diseases Control System consists of 8 classes as shown in Table I. In which, durian disease is the class that could be related to all classes in the ontology.

TABLE I: Classes of DuRIAN PESTS AND Diseases

\begin{tabular}{|l|l|l|}
\hline Attribute & Relation & \\
\hline Disease_ID & a/o & \\
\hline Disease_Name & a/o & \\
\hline Disease_Symptom & a/o & \\
\hline Disease_Cause & a/o & \\
\hline Disease_Outbreak & a/o & \\
\hline Disease_Prevention & a/o & \\
\hline Disease_Contagion & a/o & \\
\hline Pest_Disease & p/o & Pests \\
\hline Durian_Cultivar & p/o & Cultivars \\
\hline Symptom_Bunch & p/o & Symptoms of bunch \\
\hline Symptom_leaf & p/o & Leaf area symptoms \\
\hline Symptom_Branch & p/o & $\begin{array}{l}\text { Symptoms of branches and } \\
\text { trunk }\end{array}$ \\
\hline Symptom_fruit & p/o & Symptoms of fruit \\
\hline Symptom_Root_Growth & p/o & Symptoms of root and growth \\
\hline
\end{tabular}

\section{The Semantic Search System}

After rechecking the concept with the durian experts and checking the references in arda.or.th, the last phase of the framework is to develop the semantic search system. We used the Ontology Application Management Framework: OAM [13]. The OAM consists of 2 major components:

1) The Database to Ontology Mapping Component; we used OWL (Web Ontology Language) for mapping data from database to the ontology base. The results of mapping data will be transformed into RDF (Resource Description Framework) format.

2) The Search Configuration Component; this User Interface (UI) will be used as the query component and showing the query results. In the web-based GUI, the user can choose the pest and disease symptoms; with the configuration setting and the relations of the durian symptoms, the query results will be shown on the screen.

\section{RESULTS}

Fig. 5 shows the screen captured of Ontology-based Semantic Retrieval for Durian Pests and Diseases Control System.

Fig. 6 shows the search screen of the system, e.g. the user may search by the symptoms of bunch and the result of the search will be shown at the bottom of the screen.

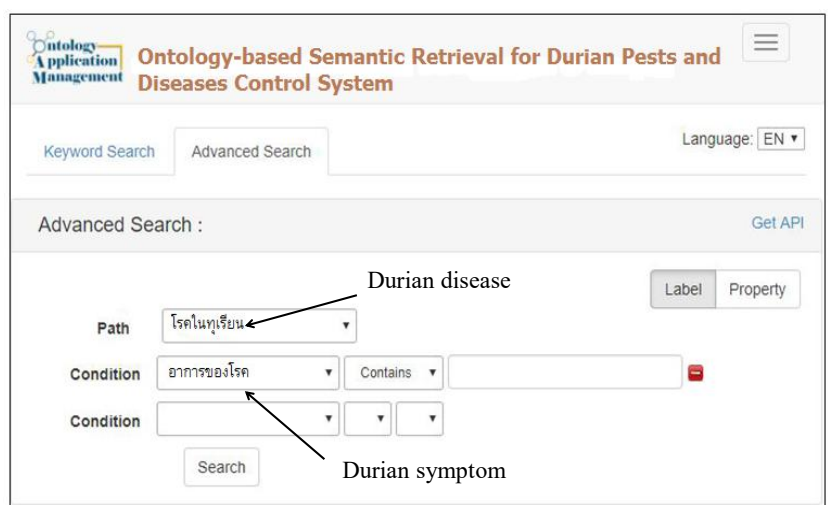

Fig. 5. The main screen of the system.

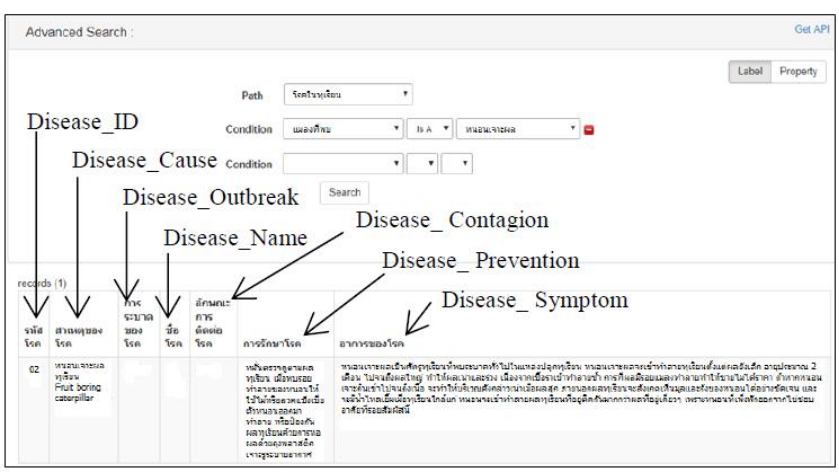

Fig. 6. The search screen and the result.

TABLE II: THE EXPERIMENTAL RESULTS

\begin{tabular}{|c|l|c|c|c|c|c|}
\hline Case & \multicolumn{1}{|c|}{ Query } & $|\boldsymbol{A}|$ & $|\boldsymbol{B}|$ & $|\boldsymbol{C}|$ & $\boldsymbol{P}$ & $\boldsymbol{R}$ \\
\hline 1 & Symptoms of bunch: White mold & 1 & 1 & 2 & 100 & 50 \\
\hline 2 & Leaf area symptoms: Burnt leaf & 1 & 1 & 1 & 100 & 100 \\
\hline 3 & $\begin{array}{l}\text { Leaf area symptoms: Pink mold } \\
\text { Symptoms of branches and trunk: } \\
\text { Pink mold }\end{array}$ & 1 & 1 & 1 & 100 & 100 \\
\hline 4 & $\begin{array}{l}\text { Symptoms of branches and trunk: } \\
\text { Shot hole borer }\end{array}$ & 2 & 2 & 3 & 100 & 66.67 \\
\hline 5 & $\begin{array}{l}\text { Symptoms of fruit: die } \\
\text { Symptoms of root and growth: die }\end{array}$ & 4 & 4 & 4 & 100 & 100 \\
\hline 6 & Symptoms of fruit: grow slowly & 2 & 2 & 3 & 100 & 66.67 \\
\hline 7 & $\begin{array}{l}\text { Symptoms of root and growth: } \\
\text { Root rot and Foot rot }\end{array}$ & 1 & 1 & 1 & 100 & 100 \\
\hline 8 & Pest: Long horned beetle & 1 & 1 & 1 & 100 & 100 \\
\hline 9 & $\begin{array}{l}\text { Symptoms of bunch: die } \\
\text { Pest: Mealy bugs }\end{array}$ & 3 & 3 & 3 & 100 & 100 \\
\hline 10 & Pest: Durian psyllid & 2 & 2 & 2 & 100 & 100 \\
\hline & & \multicolumn{3}{|c|}{ Average } & 100 & 88.33 \\
\hline
\end{tabular}

As shown in Fig. 6, by given the query of condition (Pest Disease) Is A (Fruit boring caterpillar), the results are shown below:

Disease_ID $=02$;

Disease_Cause $=$ Fruit boring caterpillar;

Disease_Prevention $=$ Check durian usually, prevent the worm by wrapping the durian fruit with a plastic cover (Perforated ventilation) [7];

Disease_Symptom $=$ Fruit boring caterpillar will destroy the durian fruit, normally found during 2-3 months after pollination and durian will be rotten and fall before its maturity. By the observation, the durian farmer may see the hole on the durian fruit and obviously see the water comes 
out [7];

We evaluated our system in terms of the precision, recall, and overall performance. Equation 1, 2, and 3 are shown below:

$$
\begin{array}{ll}
\text { Precision: } & P=|A| /|B| \\
\text { Recall: } & R=|A| /|C|
\end{array}
$$

\section{Overall performance:}

$$
\text { (F-measure) } \quad F=2\left(R^{*} P\right) /(R+P)
$$

where, $|A|=$ Number of the correct answer

$|B|=$ Number of total answers

$|C|=$ Number of total answers by the experts

The system was tested by 2 experts using 10 cases of the query. The correctness of the query results must be given by 2 experts, otherwise that case would be marked "fail". Table II shows the experimental results.

\section{CONCLUSIONS AND FUTURE WORKS}

By given 10 cases of the query, the experimental results yielded $100 \%$ of precision, $88.33 \%$ of recall, and $93.8 \%$ of F-measure. The system provides 8 classes of pests and diseases of 3 durian cultivars (Monthong, Chanee and Kanyao). We noticed that there were some errors in the case of the Burnt leaf and the Leaf spot diseases (the symptoms of these diseases have the same physical characteristics; therefore, only an experienced durian farmer can notice the different of the spots on the leaves).

The recommendations for the future such as 1) adding more pests and diseases, 2) providing the real-time update the knowledge repositories and the feature which is capable of retrieving the new knowledge for durian pests and diseases control.

\section{APPENDIX}

In Thailand, we can classified the major pests of durian into 6 types: 1) Durian seed borer, 2) Durian psyllids, 3) Fruit boring caterpillar, 4) Mealy bugs, 5) Shot hole borer, and 6) White grub [14]. Table III shows the 6 major pests of durian.

TABLE III: The 6 MAJor Pests of Durian In ThaIland
Pest name

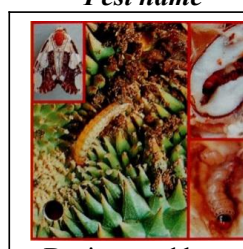

Durian seed borer

(Mudaria luteileprosa

Hollaway)

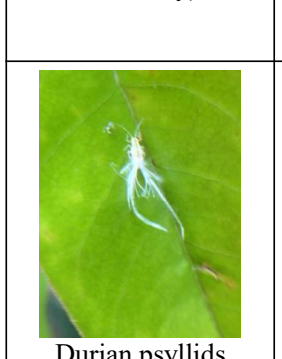

Durian psyllids

\section{Pest outbreak}

Fruit and seed

The mature durian seed borer lays eggs on the fruit near the calyx. When the fruit is 6-week old until the harvest period, it pierces through to eat the seed and excretes to dirty the flesh. The worm lives in the fruit until the fruit is mature. When the worm is mature, it will pierce through the peel to stay in the silk case underground. Most of the destroyed durian fruit are in the phase that the seed is robust [15]. In controlling seed borer, phosalone + cypermethrin is the most effective insecticide followed by endosulfan and carbaryl [16].

Psyllids larval stages on young leaf of durian [17]. Psyllids are usually found only the young leaves. Psyllids lay egg clusters into the tissues of young leaves, and feeding by nymphs and adults causes the young leaves to develop yellow spots and eventually defoliate. The Chanee variety of durian is particularly susceptible to psyllids [18]. Weekly sprays of neem oil or insecticidal soap will kill most psyllids.

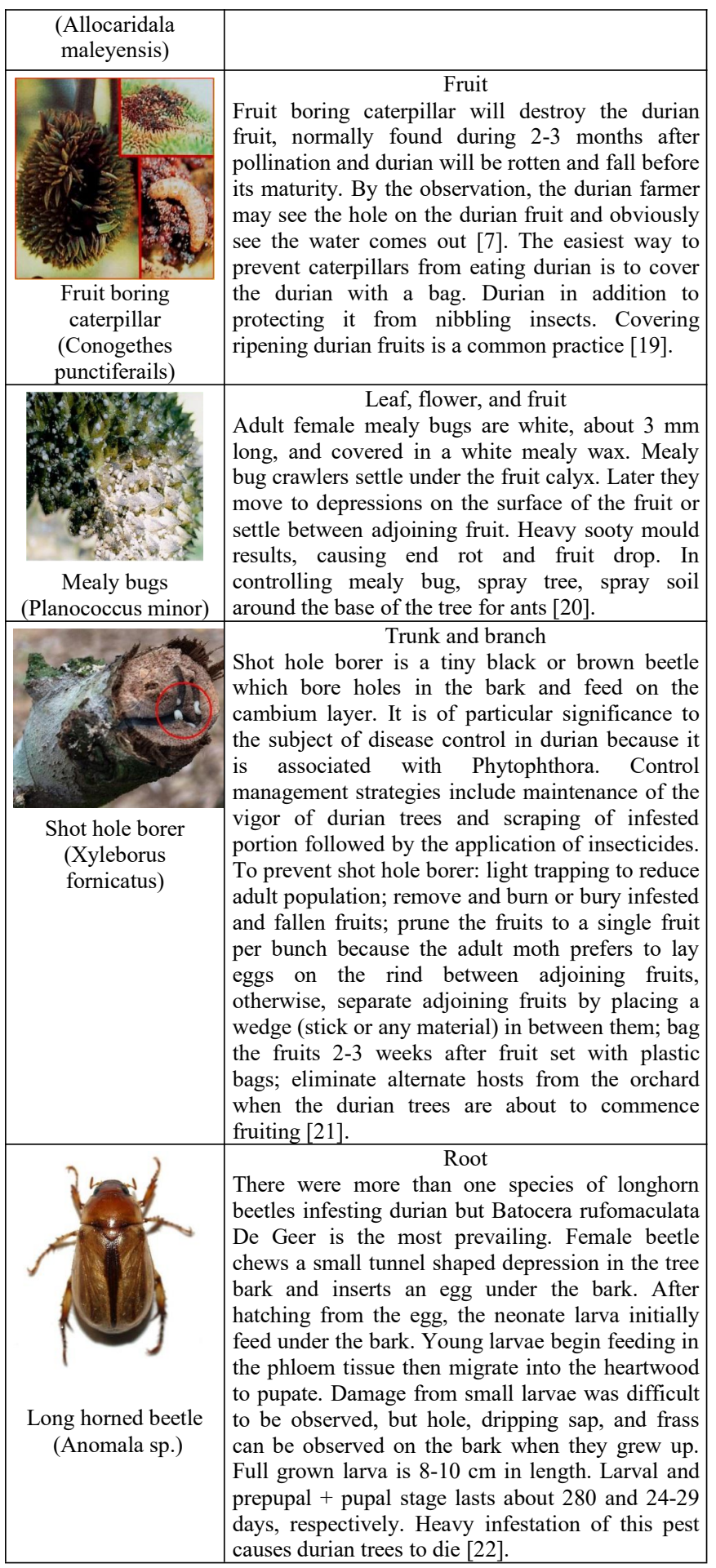

TABLE IV: THE 4 MAJOR DiseAses of DURIAN IN THAILAND Disease name

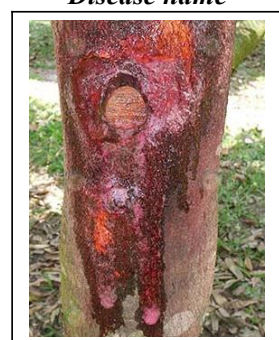

Pink mold Disease outbreak

Leaf, trunk and branch

The Pink Disease normally caused by basidiomyceae fungus also known as Corticum salmonicolor. The disease attacks the twigs and smaller branches of durian trees causing wilting and dieback. Four years and above old durian tree are subject to this attack due to bushy canopies. Those areas with heavy rainfall especially on inland area are recorded high occurrence of this disease. The silky white mycelia threads appear on the bark of small branches or twigs. This mycelial threads later change appearance to pink color as the bark dies. The infected wood turns dark brown and their leaves yellow foliage in which it drops. The branch dies and finally the disease results wilting and death of foliage on the infected twig or 


\begin{tabular}{|c|c|}
\hline & $\begin{array}{l}\text { branch. The whole tree is not killed. To prevent } \\
\text { the outbreak: wider planting distance for durian } \\
\text { tree is able to provide more air-ventilation and } \\
\text { reduce the incidence of pink disease; remove and } \\
\text { burn the infected pink disease twig or branch; the } \\
\text { use of chemical such as copper oxide, copper } \\
\text { oxychloride, copper hydroxide, triadimefen, } \\
\text { tridemorph (calixin), oxycarboxin and other } \\
\text { systemic fungicide are practical [24]. }\end{array}$ \\
\hline (Powder mold) & $\begin{array}{l}\text { Leaf, trunk and branch } \\
\text { The white disease in durian is caused by } \\
\text { Rigidoporus lignoses a type of fungi. This soil- } \\
\text { borne disease occurred if the durian is planted in } \\
\text { the area of ex-tapioca or ex-rubber plantation. } \\
\text { The disease is serious for the first } 6 \text { years of } \\
\text { durian establishment. The symptoms shown by } \\
\text { foliage wilt and changes color from green to } \\
\text { yellow than brown and finally shrivel. The durian } \\
\text { tree usually dies shortly after showing this } \\
\text { symptom [24]. }\end{array}$ \\
\hline & $\begin{array}{l}\text { Fruit } \\
\text { Fruit rot normally found on all } 4 \text { cultivars of } \\
\text { durians but higher percentages were found on the } \\
\text { Chanee variety of durian }[25] \text {. The fruit rot after } \\
\text { harvesting caused by several fungal pathogens } \\
\text { including P. durionis is considered to be more } \\
\text { significant in losses of durian yield [26]. Post- } \\
\text { harvest of fruit rot can be minimized by more } \\
\text { frequent fruit picking. The ideal fruit picking } \\
\text { about } 2-3 \text { time a day and brush all dirt (soils, } \\
\text { leaves others) immediately. To reduce the fruit } \\
\text { falling impact to the ground, the farmers may } \\
\text { construct nylon or wire netting beneath the tree } \\
\text { during ripening periods. The durian fruit fall to } \\
\text { the netting reduce the damage and fruit rot } \\
\text { problem [27]. }\end{array}$ \\
\hline Burnt leaf & $\begin{array}{l}\text { Leaf } \\
\text { Burnt leaf usually occurs on the surfaces of the } \\
\text { leaves. It may appear on the twigs and branch or } \\
\text { durian bark of the durian trunk. This disease is } \\
\text { not parasitic to the tree but the appearance on the } \\
\text { leaves reduces the photosynthesis activity such as } \\
\text { transpiration and respiration. To eradicate this } \\
\text { disease; use spray chemical such as copper or oil } \\
\text { base to the infected parts. The effective method is } \\
\text { spraying during the disease is dry [24]. }\end{array}$ \\
\hline
\end{tabular}

Normally, the diseases of durian can be found in the other fruits, e.g. the major diseases of durian are Fruit rot, Pink mold, White mold, and Burnt leaf [23] (See Table IV).

\section{CONFLICT OF INTEREST}

The author declares no conflict of interest.

\section{REFERENCES}

[1] H. E. Win, "Analysis of tropical fruits in Thailand," 2017.

[2] S. Parichatnon, K. Maichum, and K. Peng, "Measurement of technical efficiency of durian production in Thailand: An application of data envelopment analysis approach," IRA-International Journal of Management and Social Sciences, 2017, vol. 6, pp. 486-494.

[3] K. Kubo and S. Sakata, "Impact of China's increasing demand for agro produce on agricultural production in the Mekong region," $B \mathrm{RC}$ Research Report Bangkok Research Center, JETRO Bangkok/IDEJETRO, 2018.

[4] F. Pensiri and P. Visutsak, "Durian cultivar recognition using discriminant function," in Proc. 2nd International Conference on Information Technology, 2017.

[5] F. Pensiri and P. Visutsak, "The watershed segmentation for durians classification," in Proc. ACM International Conference Proceeding Series, International Conference on Image and Graphics Processing, Hong Kong, February 24-26, 2018.

[6] M. A. Musen, "An overview of knowledge acquisition," Second Generation Expert Systems, Springer-Verlag New York, Inc., 1993, pp. 405-427.
[7] Arda Kasetinfo south durian. [Online]. Available: http://www.arda.or.th/kasetinfo/south/durian/controller/01-08.php

[8] S. Staab, R. Studer, and H. P. Schnurr, "Knowledge processes and ontologies," IEEE Intelligent Systems, vol. 16, pp. 26-34, 2001.

[9] N. F. Noy and D. L. McGuinness, "Ontology development 101: A guide to creating your first ontology," 2001.

[10] M. A. Musen, "The protégé project: A look back and a look forward. AI matters," Association of Computing Machinery Specific Interest Group in Artificial Intelligence, vol. 1, no. 4, June 2015.

[11] M. Riichiro, S. Eiichi, K. Kouji, and K. Yoshinobu, "The model of roles within an ontology development tool: Hozo," Appl. Ontol., vol. 2, no. 2, pp. 159-179, 2007.

[12] M. Buranarach, N. Chalortham, P. Chatvorawit, Y. Thein, and T. Supnithi, "An ontology-based framework for development of clinical reminder system to support chronic disease healthcare," Ministry of Public Health, Nonthaburi, 2009.

[13] M. Buranarach, Y. Thein, and T. Supnithi, "A community-driven approach to development of an ontology-based application management framework," in Proc. Joint International Semantic Technology Conference, Springer, Berlin, Heidelberg, 2012, pp. 306312.

[14] Chantaburi images. [Online]. Available: http://doa.go.th/hrc/chantaburi/images/files/insect_du.pdf

[15] S. Sudhi-Aromna, "Integrated insect pests management technology to reduce durian seed borer," 2003.

[16] S. Sudhi-Aromna, "Appropriate fruit bagging time for preventing durian seed borer, Mudaria iuteileprosa Holloway," 1998.

[17] C. D. Butler and J. T. Trumble, "The potato psyllid, Bactericera cockerelli (Sulc) (Hemiptera: Triozidae): Life history, relationship to plant diseases, and management strategies," Terrestrial Arthropod Reviews, vol. 5, no. 2, pp. 87-111, 2012.

[18] D. Burckhardt, D. Ouvrard, D. Queiroz, and D. Percy, "Psyllid hostplants (Hemiptera: Psylloidea): Resolving a semantic problem," Florida Entomologist, vol. 97, no. 1, pp. 242-246, 2014.

[19] W. Ritudompol, "Knowledge needs of the durian growers for durian production improvement in Amphoe Lablae, Changwat Uttaradit [Thailand]," 1991.

[20] R. A. Cloyd and A. Dickinson, "Effect of insecticides on mealybug destroyer (Coleoptera: Coccinellidae) and parasitoid Leptomastix dactylopii (Hymenoptera: Encyrtidae), natural enemies of citrus mealybug (Homoptera: Pseudococcidae)," Journal of Economic Entomology, vol. 99, no. 5, pp. 1596-1604, 2006.

[21] Tips to control durian phytophthora and insect pests. [Online]. Available: https://www.cropsreview.com/phytophthora.html

[22] X. Cheng, R. Sardana, H. Kaplan, and I. Altosaar, "Agrobacteriumtransformed rice plants expressing synthetic cryIA (b) and cryIA (c) genes are highly toxic to striped stem borer and yellow stem borer," in Proc. the National Academy of Sciences, vol. 95, no. 6, pp. 2767-2772, 1998.

[23] Neweto plant. [Online]. Available: http://eto.ku.ac.th/neweto/ e book/plant/r_plant/rplant10.pdf

[24] Durian, trunk and branch disease. [Online]. Available: http://animhosnan.blogspot.com/2013/12/durian-trunk-and-branchdisease.html

[25] Phytophthora fruit rot of durian. [Online]. Available: http://agris.fao.org/agris-search/search.do?recordID=AU9401224

[26] V. Tongsri, P. Songkumarn, and S. Sangchote, "Leaf spot characteristics of Phomopsis durionis on durian (Durio Zibethinus Murray) and latent infection of the pathogen," Acta Universitatis Agriculturae et Silviculturae Mendelianae Brunensis, vol. 64, no. 1, pp. 185-193, 2016.

[27] T. K. Lim, "Durian: diseases and disorders," Tropical Press, 1990.

Copyright $\odot 2021$ by the authors. This is an open access article distributed under the Creative Commons Attribution License which permits unrestricted use, distribution, and reproduction in any medium, provided the original work is properly cited (CC BY 4.0).

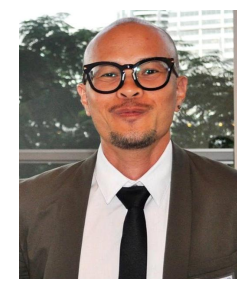

Porawat Visutsak received a BEng in industrial engineering in 1998 from the Faculty of Engineering, Kasetsart University, an MSc in information technology in 2001 from the School of Information Technology, King Mongkut's University of Technology Thonburi (KMUTT), and a $\mathrm{PhD}$ in computer science in 2012 from the Faculty of Science, King Mongkut's Institute of Technology Ladkrabang (KMITL). He was a research fellow at Sun Moon University, Republic of Korea in 2010. 
He was an assistant to dean in information technology affairs at the Faculty of Liberal Arts and Science, Kasetsart University and Committee Chairman in BSc (Special Program) at the Computer Division from 2010 to 2012. Dr. Visutsak has been with King Mongkut's University of Technology North Bangkok (KMUTNB) since 2013, he is now assistan professor in the Department of Computer and Information Science, Faculty of Applied Science. He is also a research fellow of National Research Council of Thailand. His current research interests are medical imaging, machine visions.

$\mathrm{He}$ has been selected to receive a 2016 Endeavour Research Fellowship to conduct his research at the University of Southern Queensland, Australia. In 2016 round, the Endeavour Scholarships and Fellowships have been offered to 500 high achieving international recipients for an opportunity to study in Australia to further their skills and knowledge overseas while building their international awareness. The Endeavour Scholarships and Fellowships are internationally competitive and promote knowledge, education links and enduring ties between Australia and participating countries around the world.

$\mathrm{He}$ has also been awarded the Junior Research Fellowship 2017 to conduct the research at Centre de Recherche en Informatique, Signal et Automatique de Lille, France. The Junior Research Fellowship Program supports Thai post doctorates who intend to spend 2 to 6 months scientific stay in a laboratory in France. This program is supported by Ambassade de France en Thailande. 